\title{
Elevated exhaled nitric oxide in patients with hepatopulmonary syndrome
}

\author{
G. Cremona*, T.W. Higenbottam*, V. Mayoral**, G. Alexander ${ }^{+}$, E. Demoncheaux*, \\ C. Borland*, P. Roe**, G.J. Jones**
}

Elevated exhaled nitric oxide in patients with hepatopulmonary syndrome. G. Cremona, T.W. Higenbottam, V. Mayoral, G. Alexander, E. Demoncheaux, C. Borland, P. Roe, G.J. Jones. @ERS Journals Ltd 1995.

ABSTRACT: The hypoxaemia of hepatopulmonary syndrome, seen in severe chronic liver dysfunction, occurs as a result of precapillary pulmonary arterial dilatation and arteriovenous communications. These abnormalities contribute to the mismatch between ventilation and perfusion, and the right to left blood flow shunting. Nitric oxide (NO) is a powerful vasodilator concerned with the regulation of pulmonary vascular tone in man.

Using a chemiluminescence analyser, we have measured endogenously produced NO in the exhaled air of three patients with the hepatopulmonary syndrome, six normoxaemic cirrhotic patients and six healthy volunteers. The subjects breathed NO-free air throughout the measurements.

The molar rate of production of exhaled NO was raised almost threefold in the patients with hepatopulmonary syndrome compared with normal volunteers and with normoxaemic cirrhotic patients. Hypoxia per se, achieved in the normal volunteers by breathing a hypoxic gas mixture, reduced rather than increased the exhaled NO. One hepatopulmonary syndrome patient received an orthotopic liver transplant and achieved normoxaemia after 3 months. The exhaled NO also returned to normal.

Increased pulmonary production of NO could contribute to the development of the hepatopulmonary syndrome.

Eur Respir J., 1995, 8, 1883-1885.

The hepatopulmonary syndrome develops in some patients with severe chronic liver dysfunction of varied aetiology. It is characterized by profound hypoxaemia, which worsens when rising from supine to upright posture, so-called orthodeoxia [1]. Associated with the syndrome there are pulmonary arteriovenous communications and dilatation of precapillary pulmonary arteries [2]. This causes right-to-left shunting of blood flow and mismatch between ventilation and perfusion [3]. Increased endogenous production of nitric oxide (NO) has been proposed as an important determinant of the hyperdynamic circulation of the cirrhotic patient [4]. In many mammalian species, including man, endothelial NO contributes to the normally low pulmonary vascular tone [5]. Inhaled NO is a potent pulmonary vasodilator, which acts selectively on the pulmonary circulation being rapidly inactivated by haemoglobin [6]. It is now possible to measure NO produced in the lung [7, 8] and upper airway [9] from the concentration of NO in the exhaled air. We have used this approach to determine whether the patient with hepatopulmonary syndrome produces an excess amount of NO in the lung.
*Dept of Respiratory Physiology, and University Depts of **Anaesthesia and Medicine, Addenbrookes Hospital, Cambridge, UK.

Correspondence: T.W. Higenbottam Section of Respiratory Medicine Dept of Medicine and Pharmacology Floor $\mathrm{F}$

10 Beech Hill Rd

Sheffield S10 2RX UK

Keywords:

Hepatopulmonary syndrome nitric oxide (NO)

Received: August 171994

Accepted after revision June 231995

\begin{abstract}
Subjects and methods
Our local hospital had given ethical approval for the study. Twelve healthy volunteers, six patients with cirrhosis and three patients with cirrhosis and severe hypoxia were studied. All the cirrhotic patients were awaiting orthotopic liver transplantation, selection criteria have been reported in full previously [10]. The liver biopsies showed evidence of chronic active hepatitis $(n=2)$, cryptogenic cirrhosis $(n=5)$, primary biliary cirrhosis $(n=1)$ and primary sclerosing cholangitis $(n=1)$. No patient with evidence of airways obstruction was included. The severe hypoxaemic cirrhotics all showed evidence of orthodeoxia and of intrapulmonary shunting.

The measurement of exhaled NO was undertaken with the subjects semirecumbent. They were asked to inhale and exhale through a two-way non-rebreathing valve; their noses were blocked with nose clips throughout the measurement. For $10 \mathrm{~min}$, they inhaled NO-free air (British Oxygen Company (BOC) Specialist Gases Ltd; Guildford, Surrey, UK), which was held in a $100 \mathrm{~L}$ Douglas bag. Sampling of the Douglas bag showed that it contained less than 1 part per billion (ppb) NO. The
\end{abstract}


exhaled air was collected in another 100 L Douglas bag during the $10 \mathrm{~min}$ period. The normal volunteers also breathed a NO-free hypoxic gas mixture of $10 \%$ oxygen $\left(\mathrm{O}_{2}\right)$ for a 10 min period, during which the exhaled air was collected. During the hypoxic gas breathing, the arterial $\mathrm{O}_{2}$ saturation $\left(\mathrm{Sa}_{\mathrm{a}} \mathrm{O}_{2}\right)$ was monitored with a pulse oximeter (Minolta, DeVilbiss, Middlesex, UK).

The concentration of exhaled NO was measured with a chemiluminescence analyser (model 42, Thermoelectron, Warrington, UK). It was calibrated against standard gas mixtures to enable measurements of $\mathrm{NO}$, with a sensitivity of $0.5 \mathrm{ppb}$. The minute exhaled volume was measured using a Wright's Respirometer (BOC, Guildford Surrey, UK). This device was in circuit with the expiratory port of the two-way valve. The molar rate of production of NO by the lung was calculated by multiplying the concentration of exhaled NO by $10^{9}$ to convert to fractional concentration. This is the multiplied by the minute volume, after correcting for atmospheric pressure and temperature.

All patients had chest radiographs, spirometry and gas transfer for carbon monoxide $(T \mathrm{~L}, \mathrm{CO})$ undertaken. Right heart cardiac catheterization was performed in the three patients with severe hypoxia. Recordings of mixed venous $\left(\mathrm{Cv}, \mathrm{O}_{2}\right)$ and radial arterial blood $\left(\mathrm{Ca}, \mathrm{O}_{2}\right)$ oxygen contents were made, which were use in the shunt equation: $\mathrm{Cc}, \mathrm{O}_{2}-$ $\mathrm{Ca}, \mathrm{O}_{2} / \mathrm{Cc}, \mathrm{O}_{2}-\mathrm{Cv}_{v}, \mathrm{O}_{2}$, to calculate the shunt fraction, where $\mathrm{Cc}, \mathrm{O}_{2}$ is the pulmonary capillary oxygen content.

Results were expressed as mean \pm standard deviation (SD). Student's t-test for unpaired data was used to compare differences between groups. The p-values less than 0.05 were taken as significant.

\section{Results}

The cirrhotic patients without hypoxaemia had clear chest radiographs and normal lung function, including $T$ L,CO (table 1). Pulse oximetry values ranged $95-97 \%$ (table 1 ). The hypoxaemic patients had reduced $T \mathrm{~L}, \mathrm{CO}$ values (table 1), but normal chest radiographs. They were hypoxaemic and had significant shunt fractions (table 1).

In the semirecumbent position, the normal subjects and the nonhypoxaemic cirrhotics had normal values of exhaled
NO (table 1). By contrast, the hypoxaemic cirrhotics had twice the amount of NO in the exhaled breath (table 1) compared with normals and the nonhypoxaemic cirrhotics. Three months after orthotopic liver transplantation, one hypoxaemic patient had normal arterial blood gas tensions and the exhaled NO production had been restored to normal.

Exposure of the normals to a hypoxic gas mixture caused a fall in the $\mathrm{Sa}_{\mathrm{a}} \mathrm{O}_{2}$ from $98 \pm 2$ to $81 \pm 4 \%$, and a slight fall in the rate of production of $\mathrm{NO}$ by the lung from $3.3 \pm 1.6$ to $2.8 \pm 1.6 \mathrm{nM} \cdot \mathrm{min}^{-1}$.

\section{Discussion}

In this small study, hypoxaemic patients with cirrhosis had elevated rates of production of NO in their lungs.

Our method of measurement allows for the slow response time for the chemiluminescence analysers [11]. Singlebreath analysis, whilst having been advocated as a simple measurement [12], is not possible with current technology. Normal subjects and the nonhypoxaemic cirrhotics had exhaled values for NO similar to earlier reports [5].

We have previously shown that mixed exhaled NO level correlates with the TL,CO [13]. There is strong evidence from the isolated perfused and ventilated lungs that the mixed exhaled NO level reflects the rate of pulmonary vascular production [14]. Hypoxaemia per se is an unlikely cause of the elevated NO in the hypoxaemic cirrhotics, as in normals hypoxaemia was associated with a slight fall in exhaled NO. This is in keeping with the observed fall in the exhaled NO levels in the isolated lung with hypoxaemia [14] and those observed in vivo in guinea-pigs [7]. From these observations, we would have anticipated that the hypoxaemic cirrhotic patients would have had reduced exhaled NO levels. The converse was the case, suggesting increased production of NO in the lungs of patients with hypoxaemia and cirrhosis. This idea is supported by the restoration of a normal level of NO in the one patient who underwent successful orthotopic liver transplantation in association with return to normoxaemia. Liver transplantation can reverse the ventilation-perfusion mismatch seen in the hepatopulmonary syndrome and restore normoxaemia [15].

Table 1. - Lung function, arterial blood gases and rate of production of nitric oxide

\begin{tabular}{|c|c|c|c|c|c|c|}
\hline & \multicolumn{3}{|c|}{ Hepatopulmonary patients } & \multirow{2}{*}{$\begin{array}{c}\text { Cirrhotic controls } \\
(\mathrm{n}=6) \\
\text { Breathing air }\end{array}$} & \multicolumn{2}{|c|}{ Normal controls } \\
\hline & $\begin{array}{c}\text { No. } 1 \\
\text { Breathing air }\end{array}$ & $\begin{array}{c}\text { No. } 2 \\
\text { Breathing air }\end{array}$ & $\begin{array}{l}\text { No. } 3 \\
\text { Breathing air }\end{array}$ & & $\begin{array}{l}\quad(\mathrm{n}=18) \\
\text { Breathing air }\end{array}$ & $\begin{array}{l}(\mathrm{n}=12) \\
\text { Breathing } \\
10 \% \mathrm{O}_{2}\end{array}$ \\
\hline$T \mathrm{~L}, \mathrm{CO} \quad \mathrm{mmol} \cdot \mathrm{kPa}^{-1} \cdot \mathrm{min}^{-1}$ & 5.4 & 4.93 & 3.35 & $6.71 \pm 0.3$ & $8.6 \pm 0.5$ & \\
\hline $\mathrm{Pa}_{\mathrm{a}, \mathrm{O}_{2}} \mathrm{kPa}$ & 8.5 & 6.6 & 8.2 & $13.2 \pm 1.6$ & - & - \\
\hline $\mathrm{Sa}_{\mathrm{a}, \mathrm{O}_{2}} \%$ & 93 & 85 & 91 & $95-97$ & $96-100$ & $70-87$ \\
\hline Shunt fraction $\%$ & 21 & 26 & 17 & - & - & - \\
\hline MNO $\mathrm{nM} \cdot \mathrm{min}^{-1}$ & 9.2 & 8.7 & 12.5 & $3.4 \pm 1.8$ & $3.3 \pm 1.8$ & $2.8 \pm 1.6$ \\
\hline $\begin{array}{l}\text { MNO after transplantation } \\
\mathrm{nM} \cdot \mathrm{min}^{-1}\end{array}$ & 4.7 & - & & - & - & - \\
\hline
\end{tabular}

$T \mathrm{~L}, \mathrm{CO}$ : transfer factor of the lungs for carbon monoxide; $P_{\mathrm{a}, \mathrm{O}_{2}}$ : arterial oxygen tension; $\mathrm{S}_{\mathrm{a}, \mathrm{O}_{2}}$ : arterial oxygen saturation; MNO: Molar rate of production of nitric oxide. 
Nitric oxide is produced by a network of cells in the lungs [16]. It is not possible in our study to define the site of increased production in the hypoxaemic cirrhotics. The calcium independent nitric oxide synthase (iNOS) can be induced to produce nanomolar amounts of NO in most cell types [17]. This includes epithelial cells in asthmatics [18]. NO is increased in exhaled air of asthmatics [19]. Induction of iNOS in endothelial cells by cytokines and endotoxin has been suggested as the mechanism of the hyperdynamic circulation of cirrhosis [4]. Levels of circulating endotoxin [20] and cytokines [21, 22] are increased in cirrhotics. Indeed, enhanced NO production both in the systemic and pulmonary circulation could account for the reduced vascular tone seen in both circulations of cirrhotics [23]. However, we observed elevated values of exhaled NO only in the patients with hypoxaemia. The small size of our study could account for these findings, or alternatively it can be argued that the hypoxaemia in cirrhosis and elevated exhaled NO are specifically linked. This interesting finding requires further investigation, but possibly offers a clue to the mechanism causing the hepatopulmonary syndrome.

\section{References}

1. Krowka MJ, Cortese DA. Pulmonary aspects of chronic liver disease and liver transplantation. Mayo Clin Proc 1985; 60: 407-418.

2. Berthelot P, Walker JG, Sherlock S, Reid L. Arterial changes in the lungs in cirrhosis ofthe liver: lung spider naevi. N Engl J Med 1966; 274: 291-298.

3. Rodriguez-Roisin R, Roca J, Agusti ANG, Mastai R, Wagner PD, Bosch J. Gas exchange and pulmonary vascular reactivity in patients with liver cirrhosis. Am Rev Respir Dis 1987; 135: 1085-1092.

4. Vallance P, Moncada S. Hyperdynamic circulation in cirrhosis: a role for nitric oxide? Lancet 1991; 338: 776-778.

5. Cremona G, Wood AM, Hall LW, Higenbottam TW. Effects of inhibitors of nitric oxide release and action on vascular tone in isolated lungs of pigs, sheep, dog and man. J Physiol (Lond) 1994; 18: 185-195.

6. Pepke-Zaba J, Higenbottam TW, Dinh-Xaun AT, Stone D Wallwork J. Inhaled nitric oxide as a cause of selective vasodilatation in pulmonary hypertension. Lancet 1991; 338: 1173-1174.

7. Gustafsson LE, Leone AM, Persson MG, Wiklund NP, Moncada S. Endogenous nitric oxides present in the exhaled air of rabbits, guinea-pigs and humans. Biochem Biophys Res Commun 1991; 181: 852-857.
8. Borland C, Cox Y, Higenbottam TW. Measurement of exhaled nitric oxide in man. Thorax 1993; 48: 1160-1162.

9. Gerlach H, Rossaint R, Pappert D, et al. Auto-inhalation of nitric oxide after endogenous synthesis in nasopharynx. Lancet 1994; 343: 518-519.

10. Calne RY, Williams R, Rolles K. Liver transplantation in the adult. World J Surg 1986; 19: 422-431.

11. Demoncheaux EA, Maniscalco M, Roe S, Cremona G, Higenbottam TW. Exhaled nitric oxide (NO), ideas on its origin and physiological meaning. In: Superoxides and Free Radicals and Pulmonary Vascular Disease. Weir EK, Archer SL, Reeves JT, eds. NY, Futura Publishing Co., Mount Kisco, 1995.

12. Persson MG, Zetterstrom O, Agrenius V, Ihre E, Gustafsson LE. Single-breath nitric oxide measurements in asthmatic patients and smokers. Lancet 1994; 343: 146-147.

13. Cremona G, Higenbottam T, Borland C, et al. Mixed expired nitric oxide in primary pulmonary hypertension in relation to lung diffusion capacity. $Q J$ Med 1994; 87: $547-551$.

14. Cremona G, Higenbottam TW, Takao M, Hall L, Bower E. Exhaled nitric oxide in isolated pig lung. J Appl Physiol 1995; 78: 59-63.

15. Eriksson LS, Soderman C, Ericzon B-G, Eleborg L, Wahren J, Hederstierna G. Normalization of ventilationperfusion relationships after liver transplantation in patients with decompensated cirrhosis: evidence for a hepatopulmonary syndrome. Hepatol 1990; 12: 1350-1357.

16. Schmidt HHHW, Walter U. NO at work. Cell 1994; 78: 919-925.

17. Marletta MA. Nitric oxide synthase: aspects conceming structure and catalysis. Cell 1994; 78: 927-930

18. Hamid Q, Springall DR, Riveros-Moreno V, et al. Induction of nitric oxide synthase in asthma. Lancet 1993; 342: $1510-1513$.

19. Alving K, Weitzberg E, Lundburg JM. Increased amount of nitric oxide in exhaled air of asthmatics. Eur Respir $J$ 1993; 6: 1368-1370.

20. Lumsden AB, Henderson JM, Kutner MH. Endotoxin levels measured by chromogenic assay in portal, hepatic and peripheral blood in patients with cirrhosis. J Biochem Biophys Commun 1989; 18: 97-104.

21. Bird GL, Sheron N, Goka AK, Alexander G, Williams RS. Increased plasma tumour necrosis factor in severe alcoholic hepatitis. Ann Intern Med 1990; 112: $917-$ 920.

22. Sheron N, Bird G, Goka J, Alexander G, Williams R. Elevated plasma interleukin- 6 and increased severity and mortality in alcoholic hepatitis. Clin Exp Immunol 1991; 84: 449-453.

23. Hedenstiema G, Soderman C, Eriksson LS, Wahren J. Ventilation-perfusion inequality patients with nonalcoholic liver cirrhosis. Eur Respir J 1991; 4: 711-717. 